University of New Mexico

UNM Digital Repository

HSC Education Day

Health Sciences Center Events

$10-4-2019$

\title{
Predictors and Barriers to Faculty Scholarly Activity in United States Urology Residency Programs
}

David Gangwish

Martin Jurado

Carolyn A. Parshall

Fares Qeadan

Frances M.Alba

Follow this and additional works at: https://digitalrepository.unm.edu/hsc_ed_day

\section{Recommended Citation}

Gangwish, David; Martin Jurado; Carolyn A. Parshall; Fares Qeadan; and Frances M. Alba. "Predictors and Barriers to Faculty Scholarly Activity in United States Urology Residency Programs." (2019). https://digitalrepository.unm.edu/hsc_ed_day/66

This Poster is brought to you for free and open access by the Health Sciences Center Events at UNM Digital Repository. It has been accepted for inclusion in HSC Education Day by an authorized administrator of UNM Digital Repository. For more information, please contact amywinter@unm.edu. 


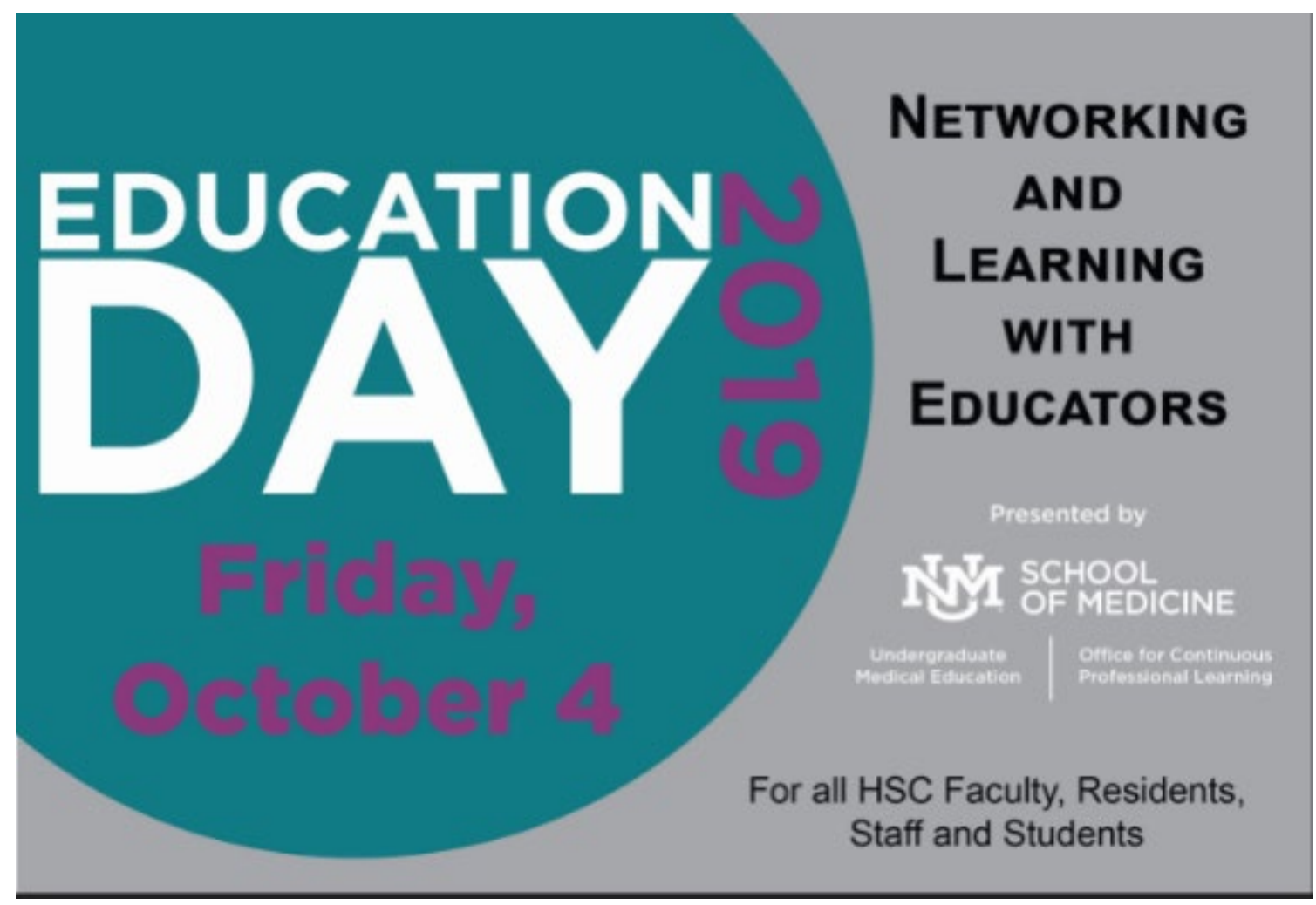

\section{Predictors and Barriers to Faculty Scholarly Activity in United States Urology Residency Programs}

David Gangwish, BS, MSIV, Martin Jurado, MSIII; Carolyn A. Parshall, M.S., and Fares Qeadan PhD, Internal Medicine; Frances M. Alba, MD, Urology

OBJECTIVE: To determine factors associated with scholarly activity among faculty members at urology residency programs. METHODS: An online survey was sent to all urology residency program directors. The survey assessed program characteristics, support and barriers for scholarly activity, and faculty participation in research and mentorship of residents. A linear regression analysis was used to identify the factors associated with faculty scholarship. Scholarly activity was defined as original research studies, systematic reviews, meta-analyses, case series and case reports. RESULTS: The survey was sent to 134 programs with a $36 \%$ response rate. Faculty attitudes toward conducting scholarly activity and lack of formal research curriculum were barriers to participation in scholarly activity, $p<0.001$ and $p=0.05$ respectively. Faculty attitudes were also a barrier to mentorship of residents $(p=0.0038)$ and publication of at least one paper $(p=0.0035)$. Having a statistician was positively associated with publications ( $p=0.062)$ and presentations $(p=0.032)$. A minimum requirement of a 'local presentation' $(p=0.04)$ and chairman support $(p=0.015)$ were positively associated with presentations at a conference. CONCLUSIONS: This study identified resources and barriers to faculty member scholarly activity. The production of scholarly activity by faculty is increased by a chairman who supports research, availability of a statistician, submitting a manuscript as a resident requirement, and a dedicated research track for residents in the program. Urology residencies seeking to prioritize scholarly activity should consider these factors. 